International Journal of Business Economics (IJBE)

Vol, 1 Issue 2, pp 128-144, March 2020

http://jurnal.umsu.ac.id/index.php/ijbe

eISSN 2686-472X

ORIGINAL ARTICLE

\title{
The Improving Model of the Quality of Financial Statements and Successful Implementation of Local Financial Information Systems
}

\author{
Irfan $^{1}$, Eka Nurmala Sari ${ }^{1}$, Muhyarsyah $^{2}$, Siti Irafah $^{1}$
}

\begin{abstract}
This study aims to (1) examine and analyze the influence of Human Resource (SDM) competence and the role of internal audit on the successful implementation of the Local Financial Information System (SKID) partially and simultaneously, (2) examine and analyze the competence of SDM and the role of internal audit on the quality of financial report partially and simultaneously,(3) examine and analyze the influence of SDM competence and the role of internal audit on the quality of financial reports on the successful implementation of the SKID. The object of this study is all provincials and district / city governments throughout North Sumatera. The sample of this study was 34 (thirty four). The data was collected by questionnaire, documentation, and interview methods. The analysis method used was path analysis using SPSS Program. The results of this study indicate that (1) SDM competence and the role of internal audit have no partial effect on the successful implementation of SKID (2) SDM competence, the role of internal audit doesn't simultaneously affect the successful implementation of SKID (3) SDM competence and the role of internal audit have a significant effect partially to the quality of financial reports (4) the successful implementation of SKID has no effect on the quality of financial reports (5) SDM competence, the role of internal audit, the successful implementation of SKID simultaneously affects the quality of financial reports (6) SDM competence and the role of internal audit have no effect on quality financial reports through the successful implementation of the local financial information system.
\end{abstract}

Keywords: : Human Resource Competence, Role of Internal Audit, Successful Implementation of Local Financial Information System, Quality of Financial Report

DOI : https://doi.org/10.30596/ijbe.v1i2.5912

JEL Classification: A19, G00, G30, L15

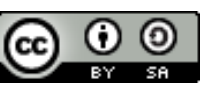

Published by International Journal of Business Economics (IJBE), Indonesia | Copyright (C) 2020 by the Author(s) | This is an open access article distributed under the Creative Commons Attribution License http://creativecommons.org/licenses/by/4.0), which permitsunrestricted use, distribution, and reproduction in any medium, provided the original work is properly cited.

Cite this article as:

Irfan., Sari, E. N., Muhyarsyah., and Irafah, S. (2020). The Improving Model of the Quality of Financial Statements and Successful Implementation of Local Financial Information Systems. International Journal of Business Economics (IJBE), 1(2), 102-116.

${ }^{1}$ Universitas Muhammadiyah Sumatera Utara

Jl. Kapten Mukhtar Basri No. 3 Medan 20221, Indonesia

${ }^{2}$ Universitas Mercu Buana, Jakarta, Indonesia

Corresponding Author: dr.irfan@umsu.ac.id 


\section{International Journal of Business Economics (IJBE)}

Vol, 1 Issue 2, pp 128-144, March 2020

http://jurnal.umsu.ac.id/index.php/ijbe

eISSN 2686-472X

\section{INTRODUCTION}

The phenomenon that occurs in Indonesia in the era of public sector reform today is the strengthening of demands for transparency and public accountability from all bureaucratic activities to the reporting stage as a form of government accountability to the public because in principle, the government that the funding sources are from the public which the activities are for the public interest must be transparent as a form of government accountability to the community. One of the accountability in government administration which is regulated in Law Number 17 of 2003 concerning State Finance and Laws Number 32 of 2004 concerning Regional Government. Concrete efforts to achieve transparency and accountability in the management of government finances, both central and regional governments, are to submit accountability reports in the form of financial reports. The financial statements will be used by interested parties as a basis for making decisions. Therefore, the information contained in the Financial Statements must be of high quality so that it is useful and in accordance with the needs of the users. Information will be useful if it has value. These values include Quality

The phenomenon that occurs in Indonesia in the era of public sector reform today is the strengthening of demands for transparency and public accountability from all bureaucratic activities to the reporting stage as a form of government accountability to the public because in principle, the government that the funding sources are from the public which the activities are for the public interest must be transparent as a form of government accountability to the community. One of the accountability in government administration which is regulated in Law Number 17 of 2003 concerning State Finance and Laws Number 32 of 2004 concerning Regional Government. Concrete efforts to achieve transparency and accountability in the management of government finances, both central and regional governments, are to submit accountability reports in the form of financial reports. The financial statements will be used by interested parties as a basis for making decisions. Therefore, the information contained in the Financial Statements must be of high quality so that it is useful and in accordance with the needs of the users. Information will be useful if it has value. These values include Quality (Arfianti, 2011).

The preparation of quality financial reports must meet accounting standards, which have reliable and relevant quality. Thus the information in the financial statements has a useful value for the reader. In addition, the same treatment of recognition and measurement of financial transactions will make the information in the financial statements comparable. Accounting standards will also be the criteria for assessing the performance of the government's financial performance.

The theory by Cohen, (2005) states that the quality financial statements do not have to comply with predetermined accounting standards, but must be accompanied by an external audit report containing an opinion or opinion on the reliability and compliance in the preparation of these financial statements. The audit opinion provides assurance that the financial statements have been prepared in accordance with accounting standards, and that the financial position, results of operations and the amount of the surplus or deficit have been fairly presented from the organization being audited. In addition, an audit report also has an important role in preventing the emergence of low quality information.

Quality is an important element of information value related to decision making by various parties. Reliability is the ability of information to provide assurance that the information is correct or valid, while timeliness is the availability of information for decision makers when needed before the information loses its power to influence decisions. The financial report is said to be of high quality if it is in accordance with the established 


\section{International Journal of Business Economics (IJBE)}

Vol, 1 Issue 2, pp 128-144, March 2020

http://jurnal.umsu.ac.id/index.php/ijbe

eISSN 2686-472X

Government Accounting Standards (SAP). One of them is that they must meet qualitative characteristics. In PP No. 71 of 2010 states that the characteristics of financial statements are: relevant, reliable, comparable and understandable. The form of financial reports consists of Budget Realization Report, Balance Sheet, Cash Flow Statement, and Notes to Financial Statements.

Annual Government Financial Reports are examined and receive an assessment in the form of an opinion from the Audit Board of the Republic of Indonesia (BPK) RI. Investigation of Financial Statements aims to provide an opinion on the fairness of financial information presented based on conformance with Government Accounting Standards (SAP), adequacy of disclosure, compliance with statutory provisions. In providing an opinion on the Government Financial Report, there are five types of opinions given by BPK RI, namely: Unqualified Opinion (WTP), Unqualified Opinion With Explanatory Paragraphs (WTP DPP), Qualified Opinion (WDP), Adversed Opinion (TW), and a statement of refusing to give an opinion or not to give an opinion (TMP) (disclaimer of opinion). When the BPK provides an Unqualified Opinion (WTP) on the Financial Statements, it means that it can be said that the financial statements of a government entity are presented and disclosed fairly and with quality, because the WTP opinion is an audit opinion issued if the financial statements are deemed to provide information that is free from error material serving.

The opinion given on the financial report is a reflection of the quality of financial accountability for the implementation of the Budget provided by the government. The change in the increase in opinion on government financial reports, for example from WDP to WTP in general, has illustrated an improvement in financial accountability by the government in presenting financial reports in accordance with applicable principles. Efforts to improve the quality of financial reports are also in line with (Inpres No 4 Tahun 2011, 2011) regarding the Acceleration of Quality Improvement of State Financial Accountability.

In order to achieve quality financial reports, the government reforms state finances through a package of Laws on state finance so that reforms in accounting and financial reporting are implemented properly. In 2005, the Government defined Government Regulation (PP) Number 24 of 2005 concerning Government Accounting Standards (SAP) which applies to the Central Government and Local Governments. The publishing of PP simultaneously, a new chapter has begun in the history of government financial accountability and financial report in Indonesia. For the first time, Indonesia has an accounting standard that becomes a reference for every government unit in preparing financial reports.

To be able to arrange financial reports in accordance with SAP, in the process of implementing SAP, it must be supported by a series of manual and computerized procedures, starting from data collection, recording, summarizing to reporting the financial position and financial operations of the central and local governments carried out by the State Civil Administration. This set of procedures is known as the accounting system. One of the accounting information systems that have been established by the government is the Accrualbased Accounting System. In 2010 the government issued Government Regulation (PP) No $71 / 2010$ to replace Governmental Regulation No. 24/2005 concerning Accrual-based Government Accounting Standards, this regulation was made in order to create national uniformity in the application of accounting treatment and presentation of financial statements so as to minimize differences central government accounting systems and local government accounting systems that may cause in difficulties in data consolidation.

In the process of applying accrual-based accounting, there are many difficulties encountered by the government so that its implementation is delayed. Limited Human Resources who understand government accounting at SKPD cause in the slow development of 


\section{International Journal of Business Economics (IJBE)}

Vol, 1 Issue 2, pp 128-144, March 2020

http://jurnal.umsu.ac.id/index.php/ijbe

eISSN 2686-472X

the Local Government accounting system. In addition, local governments have not fully utilized information technology-based accounting applications, thus slow down the application of accrual-based government accounting to local governments (Wahyudi, 2019).

To achieve quality financial reports, the government establishes an accrual-based accounting system for all central and local governments. In the successful application of accrual-based accounting, Human Resource is one of the challenges that must be considered. SDM competence is a factor that influences the successful application of the accrual-based accounting system. By the socialization / training integration program, it is hoped that stakeholders will understand and support the application of the accrual accounting basis and jointly strive to improve the quality of accountability and transparency of financial reporting (Wahyudi, 2019).

According to Roviyanti, (2009), financial reports are a product that should be produced by accounting fields or disciplines. Therefore, human resource competences are needed to be able to produce quality financial reports. Likewise government entities, to produce quality local government financial reports requires human resources who understand and competent in government accounting, regional finance, even organizational about the government.

As explained by Wahyono, (2004) in producing valuable / reliable information, it involves two main elements, namely the information generated and the resources that produce it. Information must be understood as an indicator of the quality of information. It is easy to understand here regarding the Human Resources who produce it. With competent human resources in using the system, the time for making financial reports can be saved. This is because these human resources have already had the knowledge and understanding of things that must be done, so that the financial statements that are prepared can be completed and presented on time. The faster the financial statements are presented, it is getting better that it will be presented in terms of decision making (Mardiasmo, 2002). Human resource competence is the ability of an employee that is related to knowledge, skills and attitudes that directly affect their performance to achieve the desired goals.

Otherwise, if the submission of financial reports is not timely, it indicates a lack of understanding of human resources in using the system. The delay in submitting financial reports to BPK-RI is caused by two things, namely, the lack of training in Human Resources in using financial information systems and the weakness of the internal control system. Accounting Information Systems is a collection of resources such as people and equipment designed to convert financial data and other data into information, the information is communicated to decision makers (Bodnar \& Hopwood, 2006)

Internal Audit is also one of the most influential parts in implementing a system. Internal auditors play an important role in system development, especially in companies where users do not have sufficient expertise (Hall \& Singleton, 2011). Internal audit is a department / division that have already known the regulations / SOP that apply to an agency, so that auditors can oversee the internal control system implemented in an office / agency. Internal auditors who are knowledgeable about technology will know what is needed in system development so that the system cannot be used to manipulate data, thus the process of preparing financial statements will run smoothly.

Related to the findings of problems in the information system above, it shows that internal audit has an important role in achieving quality government financial reports. Based on (Peraturan Pemerintah Nomor 60 Tahun 2008, 2008) concerning SPIP. With the existence of an internal auditor (inspection / internal control), all policies and procedures are established by an organization will run efficiently and effectively. 


\section{International Journal of Business Economics (IJBE)}

Vol, 1 Issue 2, pp 128-144, March 2020

http://jurnal.umsu.ac.id/index.php/ijbe

eISSN 2686-472X

As explained in (Peraturan Pemerintah Nomor 60 Tahun 2008, 2008) internal control is the entire process of auditing, reviewing, evaluation, monitoring, and other supervisory activities on the implementation of organizational duties and functions in order to provide adequate assurance that activities have been carried out in accordance with the objectives that have been determined effectively and efficiently for the interests of the leadership in realizing good governance. Tugiman, (2006) explains that the scope of internal inspection works must include testing and evaluation of the adequacy and effectiveness of the organization's Internal Control System and the quality of the implementation of the given responsibilities. Guy et al., (2002) also explains that the scope of internal audit includes adequate examination and evaluation as well as the effectiveness of the organization's Internal Control System and the quality of performance in carrying out the assigned responsibilities.

In addition, (Tugiman, 2006), the purpose of internal audit is to assist organizational members in carrying out their responsibilities effectively. For this reason, the internal inspection will conduct analysis, assessment, and make suggestions. The objective of the inspection also includes developing effective controls at a fair cost. According to (Sukrisno, 2004) the purpose of the inspection is carried out by the internal auditor is to assist all organizational leaders (management) in carrying out their responsibilities by providing analysts, research, suggestions and comments regarding the activities they examine.

Mulyadi, (2014) states that the reliability of the information presented in the financial statements is largely determined by whether or not the accounting internal controls that apply in government are good or not. According to (Mulyadi, 2009) internal audit also has a duty to determine whether policies and procedures are established by top management have been complied with, determine whether or not the protection of organizational assets is good, determine the efficiency and effectiveness of organizational activity procedures, and determine the reliability of information are generated by an organization.

If the internal accounting controls are well designed and implemented by management in the management of the organization then the financial statements presented to interested parties will ensure accuracy and reliability. A weak internal control system will result in insecure organizational wealth, inaccurate and unreliable accounting information, insecure efficiency and management policies cannot be complied with.

Furthermore, in the findings of problems in the information and accounting systems, there are findings of SPI problems in the weaknesses of the Budget and Expenditure Implementation control system and the weaknesses of the Internal Control Structure increasing from 2014 to 2017 with the number of findings in 2014 as many as 3,756 findings then increased to 3,797 findings, if you look at it and in 2016 the number of findings also continued to increase to 3,897 and increased again in 2017 to 4,139 problem findings. There are problems found every year due to weak internal control of the Internal Control System. This is explained by Sukrisno Agoes (2006: 11) to achieve the company's goals, the internal auditor must carry out several activities and one of them is to examine and assess the goodness, adequacy and application of the management control system, internal control (SPI), and operational control others and develop effective controls that are not too expensive.

Information systems are a set of interconnected components that function to collect, process, store, and distribute information to support satisfaction and supervision within the organization (Laudon \& Laudon, 2018). (Bodnar \& Hopwood, 2006) states that a computerbased information system is a group of hardware and software designed to convert data into useful information. The use of such hardware and software is intended to produce information quickly and accurately. 


\section{International Journal of Business Economics (IJBE)}

Vol, 1 Issue 2, pp 128-144, March 2020

http://jurnal.umsu.ac.id/index.php/ijbe

eISSN 2686-472X

From the explanation above, it can be concluded that the internal auditors are in charge of overseeing SPI in an organization, if there are still findings about SPI in the financial statements, it shows that the auditors have less role in overseeing SPI to produce quality Financial Reports. Regional financial management is regulated in Government Regulation Number 58 of 2005 and Pemendagri Number 13 of 2006 Article 3 regulates regional financial management including regional financial management power, general principles and structure of the APBD as well as the design of a regional financial accounting information system starting from the procedures for drafting, stipulating, implementing, accountability for the implementation of the Regional Government Budget (APBD), cash management, regional financial administration, regional financial accounting and guidance and supervision of regional financial management.

A Research by (Septiana, Syofyan, \& Agustin, 2017) shows that Human Resource Competence has a positive effect on the quality of local government financial reports and the role of internal audit has no significant effect on the quality of local government financial reports. Another research by (Nazaruddin \& Syahrial, 2017) shows the role of internal audit has a significant effect on the quality of financial reports in the city government of Lhokseumawe. The research by (Syarifudin, 2014) shows that the role of Internal Audit has a significant effect on SPIP so that the better the role of Internal Audit, the more effective the application of SPIP is. Furthermore, a research by (Wati, Herawati, \& Sinarwati, 2014) shows that the regional financial accounting system has a positive and significant effect on the quality of regional financial reports.

\section{METHOD}

This study uses an explanatory research approach, which aims to explain the causal relationship between the research variables and the testing hypothesis (Nasution, et al., 2020). This study is an associative study using quantitative descriptive methods that emphasize theory testing through measurement of variables in the form of numbers, which is analyzed using statistical procedures. The study was conducted to determine how the influence of Human Resource Competence and the Role of Internal Audit on the quality of financial reports with the successful implementation of local financial information system as an intervening variable.

The research was conducted in 34 Provincial Governments and District / City Governments in North Sumatra Province, consisting of 1 Province and 33 Regencies / Cities. The population in this study was 1 Provincial Government and 33 Regencies / Cities in North Sumatra Province. The type of sampling technique used in this research is a nonprobability sampling. The nonprobability sampling is a sampling technique when all members of the population are used as samples. This is done because the population is relatively small, namely 34 local governments, so that all members of the population are sampled. The data analysis technique of this research uses path analysis. Path analysis is a technique for analyzing the causal relationship that occurs in multiple regression when the independent variable affects the dependent variable either directly or indirectly (Rutherford \& Choe, 1993). 


\section{International Journal of Business Economics (IJBE)}

Vol, 1 Issue 2, pp 128-144, March 2020

http://jurnal.umsu.ac.id/index.php/ijbe

eISSN 2686-472X

\section{RESULTS AND DISCUSSION}

The $t$ test was carried out to determine the level of significance of the partial influence of the independent variables, namely HR Competence, the Role of Internal Audit on the dependent variable (Successful Implementation of SIKD).

Table 1. Results of the t-test for Sub-structure 1 Regression

\begin{tabular}{|c|c|c|c|c|c|c|}
\hline \multirow{2}{*}{\multicolumn{2}{|c|}{ Model }} & \multicolumn{2}{|c|}{$\begin{array}{l}\text { Unstandardized } \\
\text { Coefficients }\end{array}$} & \multirow{2}{*}{$\begin{array}{c}\text { Standardized } \\
\text { Coefficients } \\
\text { Beta }\end{array}$} & \multirow[b]{2}{*}{$\mathrm{T}$} & \multirow[b]{2}{*}{ Sig. } \\
\hline & & $\mathrm{B}$ & Std. Error & & & \\
\hline \multirow[t]{3}{*}{1} & (Constant) & 48.573 & 7.315 & & 6.640 & .000 \\
\hline & HR Competence & .342 & .271 & .172 & 1.265 & .210 \\
\hline & $\begin{array}{l}\text { Role of Internal } \\
\text { Audit }\end{array}$ & -.051 & .107 & -.065 & -.479 & .634 \\
\hline
\end{tabular}

a. Dependent Variable: Successful Implementation of Financial Information System

Based on the table above, the following test results are obtained:

1. The variable $\mathrm{x} 1$ has a value of $\mathrm{t}$ count of $1.265<\mathrm{t}$ table of 1.668 with a significant level of 0.210 greater than 0.05 so it accepts Ho and rejects H1. This means that there is no influence of the HR competency variable on the successful implementation of SIKD.

2. The variable $x 2$ has a $t$ value of $-479<t$ table of 1,668 with a significant level of 0.634 , greater than 0.05 , so it accepts Ho and rejects H1. This means that there is no influence of the Role of the Internal Audit variable on the successful implementation of SIKD.

Table 2. Results of the t-test for Sub-structure 2 Regression

\begin{tabular}{|c|c|c|c|c|c|c|}
\hline \multirow{2}{*}{\multicolumn{2}{|c|}{ Model }} & \multicolumn{2}{|c|}{$\begin{array}{c}\text { Unstandardized } \\
\text { Coefficients }\end{array}$} & \multirow{2}{*}{$\begin{array}{c}\begin{array}{c}\text { Standardized } \\
\text { Coefficients }\end{array} \\
\text { Beta }\end{array}$} & \multirow[b]{2}{*}{$\mathrm{T}$} & \multirow[b]{2}{*}{ Sig. } \\
\hline & & $\mathrm{B}$ & Std. Error & & & \\
\hline \multirow[t]{4}{*}{1} & (Constant) & 14.786 & 7.888 & & 1.875 & .065 \\
\hline & HR Competence & .489 & .228 & .251 & 2.145 & .036 \\
\hline & Role of Internal Audit & .275 & .089 & .357 & 3.082 & .003 \\
\hline & $\begin{array}{lr}\text { Successful Implementation } & \text { of } \\
\text { Financial Information System } & \\
\end{array}$ & .157 & .103 & 161 & 1.525 & .132 \\
\hline
\end{tabular}

Based on the table above, the following test results can be obtained:

1. The variable $\mathrm{x} 1$ has a value of $\mathrm{t}$ count $2.145>\mathrm{t}$ table 1.668 with a significant level of 0.036 smaller than 0.05 so that Ho rejects and accepts H1. This means that there is an influence of HR Competence on the Quality of Financial Statements.

2. The variable $x 2$ has a value of $t$ count 3.082> t table 1.668 with a significant level of 0.003 less than 0.05 so that Ho rejects and accepts H1. This means that there is an influence of the role of the Internal Audit variable on the Quality of Financial Reports.

3 . The variable $y 1$ has a value of $t$ count $1.525<$ from $t$ table 1.668 with a significance level of 0.132 is greater than 0.5 so that it rejects $\mathrm{H} 1$ and accepts Ho. This means that there is no effect of SIKD's success on the Quality of Financial Reports. 


\section{International Journal of Business Economics (IJBE)}

Vol, 1 Issue 2, pp 128-144, March 2020

http://jurnal.umsu.ac.id/index.php/ijbe

eISSN 2686-472X

Furthermore, it is to evaluate the effect of all independent variables on the dependent variable together (simultaneously) in the path analysis model, the F test is used.

Table 3. Results of the f-test for Sub-structure 1 Regression

\begin{tabular}{|c|c|c|c|c|c|c|}
\hline \multicolumn{2}{|c|}{ Model } & $\begin{array}{c}\text { Sum of } \\
\text { Squares }\end{array}$ & Df & $\begin{array}{c}\text { Mean } \\
\text { Square }\end{array}$ & $\mathrm{F}$ & Sig. \\
\hline \multirow[t]{3}{*}{1} & Regression & 74.739 & 2 & 37.370 & .803 & $.452^{\mathrm{b}}$ \\
\hline & Residual & 3025.143 & 65 & 46.541 & & \\
\hline & Total & 3099.882 & 67 & & & \\
\hline
\end{tabular}

To test the simultaneous relationship between the variables $\mathrm{x} 1$ and $\mathrm{x} 2$ against $\mathrm{y} 1$ using the linearity test of the regression equation as shown in table IV-17 above, based on table IV17 , the calculated $\mathrm{f}$ value is $0.803<\mathrm{f}$ table of 3.14 and a significance of $0.452>0.05$. This shows that simultaneously the independent variables ((HR Competence and the Role of Internal Audit) have no effect on the dependent variable (Successful Implementation of SIKD) or reject $\mathrm{H} 1$.

Table 4. Results of f-test for Sub-structure 2 Regression

\begin{tabular}{|c|c|c|c|c|c|c|}
\hline \multicolumn{2}{|c|}{ Model } & $\begin{array}{l}\text { Sum of } \\
\text { Squares }\end{array}$ & df & $\begin{array}{l}\text { Mean } \\
\text { Square }\end{array}$ & $\mathrm{F}$ & Sig. \\
\hline \multirow[t]{3}{*}{1} & Regression & 908.589 & 3 & 302.863 & 9.393 & $.000^{\mathrm{b}}$ \\
\hline & Residual & 2063.529 & 64 & 32.243 & & \\
\hline & Total & 2972.118 & 67 & & & \\
\hline \multicolumn{7}{|c|}{ a. Dependent Variable: Quality of Financial Report } \\
\hline \multicolumn{7}{|c|}{$\begin{array}{l}\text { b. Predictors: (Constant), Successful Implementation of Financial Information } \\
\text { System, Role of Internal Audit, HR Competence }\end{array}$} \\
\hline
\end{tabular}

To test the simultaneous relationship between the variables $\mathrm{x} 1, \mathrm{x} 2$ and $\mathrm{y} 1$ against $\mathrm{y} 2$, the regression equation linearity test was used as shown in table IV-19 above. Based on table IV-19, the calculated $\mathrm{f}$ value is $9,393>\mathrm{f}$ table of 3.14 and a significance of $0.000<0.05$. This shows that the HR competency variable, the role of internal audit, the successful implementation of SIKD simultaneously affect the dependent variable (quality of financial reports) or accept $\mathrm{H} 1$.

\section{Discussion}

\section{The Influence of Human Resources Competence on the Successful Implementation of Local Financial Information Systems}

Based on the test results of the SPSS output above regarding the effect of human resource competence on the successful implementation of local financial information system, the partial hypothesis test is obtained which shows that the $t$ value of human resource competence is 1.265 and the t table is 1.668 with $\alpha=5 \%$. Thus $t$ count is smaller than $t$ table. A significance value of 0.210 (greater than 0.05) means that Ho is accepted and H1 is rejected. These results indicate that partially the competence of human resources has no effect on the successful implementation of local financial information system. 


\section{International Journal of Business Economics (IJBE)}

Vol, 1 Issue 2, pp 128-144, March 2020

http://jurnal.umsu.ac.id/index.php/ijbe

eISSN 2686-472X

Based on the results of the above research, it is concluded that human resource competence has no effect on the successful implementation of local financial information system. This means that the involvement of the state administration with the available information system does not make the state administration more competent in terms of managing financial statements, this is seen from the results of respondents' responses to the competency variable of human resources who are more agreeable about what state administration understand about clear roles and functions in terms of financial management, thus creating an information system is provided by district governments such as SIMDA BPKP does not increase the competency value of state administrations in managing their financial reports.

In the responses of respondents, there were 38 people who have already understood their roles and functions as ASN who managed financial reports, so that the availability of a local financial information system had no impact on the state administration.

In the responses of other respondents who agreed on the completeness of the material provided during the training that was attended by state administration because the material provided was provided according to the needs as a function of financial management so that in terms of financial management they understood how to operate the system.

As we know, according to the Decree of the Head of BKN No. 46A of 2007 competence is the ability and characteristics of State Civil Administration namely, knowledge, skills, and behavioral attitudes needed in carrying out their duties, so that State Civil Administration can carry out their duties professionally, effective and efficient.

From the statement, it is in line with the opinions of respondents who stated that they have received appropriate training and already understood their respective roles and functions so that the existence of a system does not affect managing financial statements.

The results of this study do not support the results of research (Mahdavi \& Funnell, 2003) which states that the State Administrations has a significant effect on the implementation of the accounting information system. This is in line with research (Wijayanti \& Arifin, 2017) which concluded that human resource competence has no effect on information technology. This is because they already understood the stakeholders in managing financial reports.

\section{The Influence of the Role of Internal Audit on the Successful Implementation of Local Financial Information System}

Based on the test results of the SPSS output above regarding the influence of the role of internal audit on the successful implementation of local financial information system, the partial hypothesis test is obtained which shows that the $t$ value of the role of internal audit is 0.479 and $\mathrm{t}$ table is 1.668 with $\alpha=5 \%$. Thus $\mathrm{t}$ count is smaller than $\mathrm{t}$ table. A significance value of 0.634 (greater than 0.05 ) means that Ho is accepted and H1 is rejected. This result shows that partially the role of internal audit has no effect on the successful implementation of local financial information system.

Based on the above research results, it can be concluded that the role of internal audit does not partially influence the successful implementation of local financial information system. This means that the supervision carried out by internal audit does not contribute to the existence of a financial information system in several districts in North Sumatra.

In accordance with the responses of respondents regarding the role of internal audit, respondents obtained responses of $40.3 \%$ or about 28 inspectors who agreed that internal auditors have continuously improved their professional skills, effectiveness and quality of their work. 


\section{International Journal of Business Economics (IJBE)}

Vol, 1 Issue 2, pp 128-144, March 2020

http://jurnal.umsu.ac.id/index.php/ijbe

eISSN 2686-472X

In another response, respondents also agreed with the number of respondents of around 30 inspectors who agreed that the internal auditors would not use the information obtained for personal / group interests outside the interests of the organization or in a way that is against the legislation.

From the results of the respondents' responses above, we can conclude that in an information system, internal audit may have been implemented in the financial information system used, so that auditors do not need a system to dig up information about financial management carried out by OPD, so this research shows that the role of internal audit has no effect on the successful implementation of local financial information system.

The regulation of PER / 04 / M.PAN / 03/2008 states that an auditor must has a code of ethics namely; integrity, objectivity, confidentiality and competence. By having a code of ethics in this regulation, an internal audit has expertise in his field to oversee district governments in managing their finances. In this case, an oversight may has been implemented in the information system used, so that the role of the internal audit has no influence on the existence of a regional financial information system.

Based on the results of this study, the role of Internal Audit has no effect on the Successful Implementation of SIKD. This study does not support previous research (Indra et. Al. 2014), Research (Nurbaedah, 2009) which states that the role of internal audit has an effect on the effectiveness of the application of the Local Financial Information System. This research is in line with research (Permana, 2016) which provides research results that the internal control system has no significant effect on the regional financial information system.

Based on the results of this study, the role of Internal Audit has no effect on the Successful Implementation of SIKD. This study does not support previous research (Indra et. al. 2014), The research by (Nurbaedah, 2009) which states that the role of internal audit has an effect on the effectiveness of the application of the Local Financial Information System. This research is in line with research (Permana, 2016) which provides research results that the internal control system has no significant effect on the local financial information system.

\section{The Influence of HR Competence, the Role of Internal Audit on the Successful Implementation of SIKD.}

Based on the test results of the SPSS output above regarding the effect of human resource competence and the role of internal audit, it does not affect the successful implementation of local financial information system, it is obtained simultaneous hypothesis testing which shows that the calculated $\mathrm{f}$ value is 0.803 and the $\mathrm{f}$ table is 3.14 with $\alpha=5 \%$. Thus $\mathrm{f}$ count is smaller than $\mathrm{f}$ table. The significance value of 0.452 (greater than 0.05 ) means that Ho is accepted and $\mathrm{H} 1$ is rejected.

Based on the results of research has researched by researchers, HR competence, the role of internal audit does not simultaneously influence the successful implementation of SIKD. This can be seen from the results of the respondents' responses on the effect of each partially tested variable which has no effect on the successful implementation of local financial information system.

The results of this study are explained in accordance with the results of interviews are conducted by researchers to respondents that the State Civil Administration and the supervision carried out by the inspectorate section are not entirely based on SIKD, this is because the system has been systemized which does not require a lot of human resources to process financial reports, there are even some offices that still have excess computers in which the SIKD program has been installed, and according to the results of a conversation 


\section{International Journal of Business Economics (IJBE)}

Vol, 1 Issue 2, pp 128-144, March 2020

http://jurnal.umsu.ac.id/index.php/ijbe

eISSN 2686-472X

between the researcher and one of the head of the inspectorate who stated that the inspection only uses physical financial reports, does not see the system used.

The results of this study support several previous studies, the research by (Nurbaedah, 2009) which states that the role of internal audit has an effect on the effectiveness of using SIKD. This research is in line with research by (Permana, 2016) which provides research results that the internal control system has no significant effect on the regional financial information system.

The results of this study support several previous studies, the research by (Nurbaedah, 2009) which states that the role of internal audit has an effect on the effectiveness of using SIKD. This research is in line with research by (Permana, 2016) which provides research results that the internal control system has no significant effect on the regional financial information system.

\section{The Effect of Human Resources Competence on the Quality of Financial Statements}

Based on the results of the output are used by researchers in managing data through SPSS. The results of the variable $\mathrm{x} 1$ have a value of $\mathrm{t}$ count 2.145> $\mathrm{t}$ table 1.668 with a significant level of 0.036 smaller than 0.05 so that Ho rejects and accepts H1. This means that there is an influence of HR Competence on the Quality of Financial Statements.

When viewed from the responses of respondents regarding human resource competence, there are about 28 respondents who agree that the information generated from the financial statements is clear so that it can be understood by users. This proves that the financial reports are provided by local governments already have quality values. In managing financial reports, users of the system input and output the results, so that the output issued is information called financial statements. The presentation of financial reports that users can understand indicates that the financial statements have met one of the characteristics of the quality of financial statements. This is explained by Government Regulation of RI Number 71 of 2010, concerning SAP. The part of the conceptual framework of government accounting in paragraph 35 states that there are four qualitative characteristics of financial reports, namely: relevant, reliable, comparable, understandable.

Competent human resources are one of the factors for the quality of the Financial Statements. Competence can be seen from the educational background, training, and skills expressed in carrying out tasks. Competence is a characteristic of someone who has skills, knowledge, and abilities to carry out a job (Hevesi, 2005). In the process of preparing and compiling financial reports, the government needs human resource competence, mastering government accounting (Wahyudi, 2019).

Several previous studies that support this research, were examined by (Wati et al., 2014) which stated that human resource competence has a significant effect on the quality of financial statements. This is because if the competence of human resources is good, the quality of regional financial reports will also be good so that they meet the qualitative characteristics of financial reports.

The research by (Setyowati, Isthika, \& Pratiwi, 2016) also states that competence has a significant effect on the quality of LKPD, this is because the condition of the financial department employees has been supportive and balanced by including employees in training related to accounting and regional financial management. 


\section{International Journal of Business Economics (IJBE)}

Vol, 1 Issue 2, pp 128-144, March 2020

http://jurnal.umsu.ac.id/index.php/ijbe

eISSN 2686-472X

\section{The Influence of the Role of Internal Audit on the Quality of Financial Statements}

Based on the results of the output of the SPSS program is used by the author in processing data, the value of the variable $\mathrm{x} 2$ has a value of $\mathrm{t}$ count 3.082> t table 1.668 with a significant level of 0.003 less than 0.05 so that Ho rejects and accepts H1. This means that there is an influence of the role of the Internal Audit variable on the Quality of Financial Reports.

The results of this study explain that the role of internal audit has an effect on the quality of financial reports. Judging from the responses of respondents with the number of respondents 28 people who agree regarding the matter of internal auditors constantly improving professional proficiency, effectiveness and quality of work, so that with proficiency in an auditor in his profession it will further strengthen the supervision system in preparing financial reports. An internal audience who has expertise in his / her field will produce an effective work score, therefore the value of financial statements will increase if the internal audit plays a role in accordance with the code of ethics.

The role of internal audit is also one of the factors that greatly influence the value and quality of financial reports. The reason is that with the supervision of internal audit, it will produce a good control system in accordance with procedures, with the presence of SPI; the preparation of financial reports will be of high quality.

Mulyadi, (2014) states that the reliability of the information presented in the financial statements is largely determined by whether or not the accounting internal controls that apply in government are good or not. Furthermore, according to (Mulyadi, 2007) internal audit also has a duty to determine whether policies and procedures established by top management have been complied with, determine whether or not the protection of organizational assets is good, determine the efficiency and effectiveness of procedures for organizational activities, and determine the reliability of information are generated by an organization.

This is the same with the research by (Setyowati et al., 2016) which also states that the role of internal audit has a significant effect on the quality of LKPD, this is because the role of internal audit will be able to assist the government in preparing quality and reliable government financial reports to determine the reliability of financial information is produced by SKPD.

\section{The Effect of the Successful Implementation of Local Financial Information Systems on the Quality of Financial Statements}

Based on the results of the research output are used by researchers using the SPSS program, it is obtained that the variable $\mathrm{y} 1$ has a value of $\mathrm{t}$ count 1.525 <from t table 1.668 with a significance level of 0.132 is greater than 0.5 so that it rejects $\mathrm{H} 1$ and accepts Ho. This means that there is no effect of SIKD's success on the Quality of Financial Reports.

Responding to the results of the research above, it can be seen from the responses of respondents in filling out the questionnaire that agreed that the existing accounting information system pays individual attention to system users only, with a total of 22 respondents. Based on the results of interviews are conducted by the author in distributing questionnaires, prior to the existence of an information system, financial reports can still be arranged in a systemized manner, and when compared to the financial information system provided by the local government, it shows that there is no significant effect that is felt by the state administrations in terms of managing finances.

In managing quality financial reports, information systems should be the main tool that encourages the quality of financial information. However, it is contrary to the results of the 


\section{International Journal of Business Economics (IJBE)}

Vol, 1 Issue 2, pp 128-144, March 2020

http://jurnal.umsu.ac.id/index.php/ijbe

eISSN 2686-472X

research tested by the author that the successful implementation of SIKD has no effect on the quality of financial reports.

This may be due to other parts that have a strong influence in terms of financial management, namely people who input and input financial report data or commonly known as ASN (State Civil Administration) which already have competence so that the applied information system does not really affect financial reports. There is an information system implementation carried out by each district government but if the users are not competent, the resulting financial reports will not be of high quality.

The results of this study do not support previous research conducted by (Silviana \& Antoni, 2014) which shows the application of the Local Financial Information System has an effect on the quality of LKPD because SIKD is an integrated system based on accounting standards in producing financial reports.

\section{The Influence of HR Competence, Role of Internal Audit, Successful Implementation of Local Financial Information Systems on the Quality of Financial Statements}

Based on the results of the output of the data entered into the SPSS program, the calculated $\mathrm{f}$ value is $9,393>\mathrm{f}$ table of 3.14 and a significance of $0.000<0.05$. This shows that the HR competency variable, the Role of Internal Audit, the Successful Implementation of SIKD simultaneously affect the dependent variable (quality of financial reports) or accept H1.

It is seen from the responses of the respondents regarding the competence of ASN with the highest number of respondents as many as 30 people who agree that the training material attended by ASN has been provided according to their needs as a function of financial management, so it does not require much time in training. When viewed from the responses of respondents regarding the role of internal audit with the highest number of respondents, as many as 28 people who agreed that an internal auditor had continuously improved professional proficiency, effectiveness and quality of work results, so that in the process of inspection and supervision of OPD in each district can be walked in accordance with the provisions. And if it is seen from the respondents' responses regarding the successful implementation of local financial information system which has the highest respondent's response as many as 28 people who agree on the financial information system produce information that is in accordance with the needs of the work, so that the resulting financial statements are more accurate and accountable.

In the process of preparing Financial Statements, Human Resources are the first part that must be considered, because those who will use and operate the systems used in the process of preparing financial statements are humans. If human resources are competent in operating the system, the financial report preparation process will be carried out in accordance with the specified time, so that the delivery of financial reporting time will be on time. Likewise, the role of internal audit and financial information systems, in theory, is very influential because a system is able to replace the supervisory function performed by internal auditors.

To achieve quality financial reports, the government establishes an accrual-based accounting system for all central and local governments. In the successful implementation of accrual-based accounting, Human Resource is one of the challenges that must be considered. Human resource competence is a factor that influences the successful application of the accrual-based accounting system. Through the socialization / training integration program, it is hoped that stakeholders will understand and support the application of the accrual accounting basis and jointly strive to improve the quality of accountability and transparency of financial reporting to be realized (Wahyudi, 2019). 


\section{International Journal of Business Economics (IJBE)}

Vol, 1 Issue 2, pp 128-144, March 2020

http://jurnal.umsu.ac.id/index.php/ijbe

eISSN 2686-472X

According to the results of this study, HR competence and the role of internal audit have an effect on the quality of financial reports. This is supported by research (Setyowati et al., 2016) which states that competence and internal audits have a significant effect on the quality of LKPD, this is because the condition of financial department employees has been supportive and balanced by including employees in training related to accounting and local financial management. .

The results of this study support previous research conducted by (Silviana \& Antoni, 2014) which shows that the implementation of the Local Financial Information System affects the quality of LKPD because SIKD is an integrated system based on accounting standards in producing financial reports.

The Influence of Human Resources Competence and the Role of Internal Audit on the Quality of Financial Statements through Successful Implementation of Local Financial Information Systems

Based on the results of tests carried out through the SPSS program, it was found that the output for the value of $\mathrm{x} 1$ against $\mathrm{y} 2$ through $\mathrm{y} 1$ was 0.005 smaller when compared to the direct effect value with 0.064 values. These results indicate that human resource competence and the role of internal audit do not have an indirect effect on the quality of financial reports through the successful implementation of local financial information system.

The results of this study are indeed not in accordance with several theories which state that in order to achieve quality financial reports; the government has carried out state financial reforms through a package of laws in the field of state finance so that reforms in accounting and financial reporting are implemented properly. In 2005, however, the results of this study cannot be denied because many factors cause the system to not affect the quality of financial reports; it could be due to human resources who do not have sufficient skills to operate a system to be able to compile financial reports in accordance with SAP.

So in the process of implementing SAP, it must be supported by a series of manual and computerized procedures, starting from data collection, recording, summarizing to reporting the financial position and financial operations of the central and local governments carried out by the State Civil Administration. This set of procedures is known as the accounting system. One of the accounting information systems that have been established by the government is the Accrual-based Accounting System. In 2010 the government issued Government Regulation (PP) No 71/2010 to replace Governmental Regulation No. 24/2005 concerning Accrual-based Government Accounting Standards, this regulation was made in order to create national uniformity in the application of accounting treatment and presentation of financial statements so as to minimize differences central government accounting systems and local government accounting systems that may result in difficulties in data consolidation.

As explained by (Wahyono, 2004) in producing valuable / reliable information, it involves two main elements, namely the information generated and the resources that produce it. Information must be understood as an indicator of the quality of information. It is easy to understand here regarding the Human Resources who produce it. If the internal accounting controls are well designed and implemented by management in the management of the organization, the financial statements presented to interested parties ensure accuracy and reliability. 


\section{International Journal of Business Economics (IJBE)}

Vol, 1 Issue 2, pp 128-144, March 2020

http://jurnal.umsu.ac.id/index.php/ijbe

eISSN 2686-472X

\section{CONCLUSION}

Based on the research results and conclusions that have been stated earlier, it can be concluded that the competence of Human Resources does not have a partial effect on the Successful Implementation of SIKD. The Role of Internal Audit has no partial effect on the Successful Implementation of SIKD. Human Resource Competence, the Role of Internal Audit does not simultaneously influence the successful implementation of local financial information system. HR competencies have a partial effect on the quality of financial reports. The role of Internal Audit has a partial effect on the quality of financial reports. The successful implementation of local financial information system has no partial effect on the quality of financial reports. Human resource competence, the role of internal audit, and the successful implementation of local financial information system simultaneously influence the quality of financial reports. Human resource competence and the role of internal audit have no effect on the quality of financial reports through the successful implementation of local financial information system. Based on the conclusions of the research results above, the authors suggest that every district / city government should increase the role of the supervisor (inspectorate) in overseeing financial reports. Each district government improves training for human resources who do not yet have skills in processing financial reports. The Local Financial Information System is used by each district government can now be implemented on an audit basis. By creating a system of monitoring through the system, it can facilitate internal audit in monitoring local government financial reports. The government should provide a budget for training the State Civil Administration so that ASNs have the ability in their respective fields. Each district government should further strengthen the SOP so that ASNs can work according to the specified time.

\section{REFERENCE}

Arfianti, D. (2011). Analisis Faktor-Faktor Yang Mempengaruhi Nilai Informasi Pelaporan Keuangan Pemerintah Daerah (Studi Pada Satuan Kerja Perangkat Daerah Di Kabupaten Batang). Fakultas Ekonomi Universitas Diponegoro Semarang.

Bodnar, G. H., \& Hopwood, W. (2006). Sistem Informasi Akuntansi. PT. Indeks Kelompok (9th ed.). Yogjakarta: ANDI.

Cohen, D. A. (2005). Quality of Financial Reporting Choice: Determinants and Economic Consequences. SSRN Electronic Journal, 1-55.

Guy, D. M., Alderman, C. W., \& Winters, A. J. (2002). Auditing (5th ed.). Jakarta: Erlangga.

Hall, J. A., \& Singleton, T. (2011). Information Technology Auditing and Assurance (Audit dan Assurance Teknologi Informasi). Jakarta: Salemba Empat.

Hevesi, G. A. (2005). Standards for Internal Control in New York State Government. 2005. Retrieved from www.osc.state.ny.us

Inpres No 4 Tahun 2011. (2011). Inpres No 4 Tahun 2011.

Laudon, K. C., \& Laudon, J. P. (2018). Management Information Systems. Pearson (15th ed.). New York: Pearson.

Mahdavi, G., \& Funnell, W. (2003). Public Sector Accountability And Accounting Information Systems in The Islamic Republic of Iran. International Journal of Information Science and Management (IJISM), 1(2), 32-45.

Mardiasmo. (2002). Akuntansi Sektor Publik. Yogyakarta: Andi Offset.

Mulyadi. (2009). Sistem Akuntansi (3rd ed.). Jakarta: PT. Salemba Empat.

Mulyadi. (2014). Auditing (6th ed.). Jakarta: Salemba Empat.

Mulyadi, M. (2007). Sistem Akuntansi. Jakarta: Salemba Empat. 


\section{International Journal of Business Economics (IJBE)}

Vol, 1 Issue 2, pp 128-144, March 2020

http://jurnal.umsu.ac.id/index.php/ijbe

eISSN 2686-472X

Nasution, M. I., Fahmi, M., Jufrizen, J., Muslih, M., \& Prayogi, M. A. (2020). The Quality of Small and Medium Enterprises Performance Using the Structural Equation Model-Part Least Square (SEM-PLS). Journal of Physics: Conference Series, 1477(2020), 1-7.

Nazaruddin, N., \& Syahrial, S. (2017). Pengaruh Peran Audt Internal Terhadap Kualitas Laporan Keuangan Pemerintah Daerah. Jurnal Akuntansi dan Pembangunan, 3(1), 105120.

Nurbaedah, N. (2009). Pengaruh Peran Auditor Internal Terhadap Efektivitas Sistem Informasi Akuntansi. Jurusan Akuntansi Universitas Islam Negeri Syarif Hidayatullah Jakarta.

Peraturan Pemerintah Nomor 60 Tahun 2008. (2008). Peraturan Pemerintah Nomor 60 Tahun 2008 Tentang Sistem Pengendalian Intern Pemerintah.

Permana, A. Y. (2016). Pengaruh Sistem Pengendalian Intern dan SistemInformasi Keuangan Daerah terhadap Kualitas Laporan Keuangan (StudiKasus pada Badan Pengelolaan Keuangan dan Aset Daerah Pemerintah Kota Cimahi. Universitas Komputer Indonesia.

Roviyanti, D. (2009). Pengaruh Kompetensi Sumber Daya Manusia Dan Penerapan Sistem Akuntansi Keuangan Daerah Terhadap Kualitas Laporan Keuangan Daerah (Survei Pada Organisasi Perangkat Daerah (OPD) Kabupaten Tasikmalaya). Program Sarjana Universitas Siliwangi.

Rutherford, R. D., \& Choe, M. K. (1993). Statistical Model For Causal Analysis. New York: John Wiley \& Sons. Inc.

Septiana, L., Syofyan, E., \& Agustin, H. (2017). Pengaruh Kompetensi Sumber Daya Manusia Dan Peran Audit Internal Terhadap Kualitas Laporan Keuangan Pemerintah Daerah (Studi Empiris pada Satuan Kerja Perangkat Daerah Kota Sawahlunto). Wahana Riset Akuntansi, 5(1), 945-960.

Setyowati, L., Isthika, W., \& Pratiwi, R. D. (2016). Faktor-faktor yang mempengaruhi kualitas laporan keuangan Pemerintah Daerah Kota Semarang. Kinerja: Journal of Business and Economics, 20(2), 179-191.

Silviana, S., \& Antoni, E. (2014). Pengaruh Penerapan Sistem Informasi Akuntansi Terhadap Kualitas Laporan Keuangan Pemerintah Daerah Survey pada Pemerintah Kabupaten di Seluruh Jawa Barat. Universitas Widyatama.

Sukrisno, A. (2004). Auditing (Pemeriksaan Akuntansi) (5th ed.). Jakarta: LPFE Universitas Indonesia.

Syarifudin, A. (2014). Pengaruh Kompetensi SDM dan Peran Audit Intern terhadap Kualitas Laporan Keuangan Pemerintah Daerah dengan Variabel Intervening Sistem Pengendalian Internal Pemerintah (studi empiris pada Pemkab Kebumen). Fokus Bisnis : Media Pengkajian Manajemen Dan Akuntansi, 14(2), 26-44.

Tugiman, H. (2006). Standar Profesional Audit Internal. Yogyakarta: Kanisius.

Wahyono, T. (2004). Sistem Informasi Akuntansi: Analisis Desain dan Pemograman Komputer. Yogyakarta: Andi Offset.

Wahyudi, I. (2019). Analisis kualitas implementasi akuntansi berbasis akrual. Indonesian Treasury Review: Jurnal Perbendaharaan, Keuangan Negara, dan Kebijakan Publik, 4(1), 13-22.

Wati, K. D., Herawati, N. T., \& Sinarwati, N. K. (2014). Pengaruh Kompetensi SDM, Penerapan SAP, Dan Sistem Akuntansi Keuangan Daerah Terhadap Kualitas Laporan Keuangan Daerah. Jurnal Ilmiah Mahasiswa Akuntansi Undiksha, 2(1). 
International Journal of Business Economics (IJBE)

Vol, 1 Issue 2, pp 128-144, March 2020

http://jurnal.umsu.ac.id/index.php/ijbe

eISSN 2686-472X

Wijayanti, L., \& Arifin, A. (2017). Pengaruh Kompetensi Sumber Daya Manusia, Sistem Pengendalian Intern, dan Teknologi Informasi Terhadap Kualitas Laporan Keuangan Pemerintah Daerah (Studi Empiris pada Dinas Pendapatan Pengelolaan Keuangan dan Aset Daerah (DPPKAD) Kabupaten Sukoharjo). Universitas Muhammadiyah Surakarta. 